\title{
Quality Assessment of 'OGI' made from Malted Millet
}

\author{
${ }^{1}$ A.K. Olawale, ${ }^{1}$ G.O. Oyeleke, ${ }^{1}$ E.B. Akinro, ${ }^{2 *}$ T.P. Olakunle \\ ${ }^{I}$ Department of Science Laboratory Technology, Osun State Polytechnic, Iree, Nigeria \\ ${ }^{2 *}$ Department of Applied Sciences, Osun State Polytechnic, Iree, Nigeria
}

\begin{abstract}
The study aimed at investigating the quality of ogi made from malted millet. The fermented paste was made from millet at various levels $(0,5,10 \%)$ of millet malts. The AOAC method was used for proximate composition of the samples revealed increase in moisture, crude fibre, protein and ash contents with the increasing malting levels. The level of protein increase suggests a clear value and nutritional advantage in infants, children and adults at large. It also showed from the study that there was decrease in the levels of fat and carbohydrate and viscosity. Through the quality evaluation of the samples, they were all rated acceptable and this was determined through the consumers of ogi porridge that have been well familiar with its quality. Hence, the ogi produced from malted millet contains high nutrients than those made from unmalted cereals.
\end{abstract}

Key words: Quality assessment, ogi porridge, malted millet.

\section{Introduction}

Ogi is a porridge prepared from fermented maize, sorghum or millet in West Africa. It is a popular break-fast cereal and infant weaving food in Nigeria $(1,2,3)$. According to Fashakin (4), the low-income earners find ogi as a better alternative in infant food. While Sokari (5), in the preparation of ogi for meal about $20 \mathrm{~min}$ boiling step is substituted for normal $24-48 \mathrm{~h}$ steeping of maize prior to wet milling. Ogi is used majorly alone and may be fortified with legumes as weaning food $(6,7)$. The stiff gel (Eko) can be eaten along with meat, stew, vegetable soup, steam bean cake, and "moin". Ogi generally have been implicated for kwashiorkor among infant (8) and this has led to many researcher attempt to fortify it to improve its nutritional value with plant protein sources, mellon (9), Okro (10), cowpea $(11,12)$, Soybean (13), and animal protein sources. Maize based ogi have been reported to have better protein source than sorghum based ogi when fortified with cowpea or soybean (13). Fortification has been reported to improve protein from $1.4 \%$ to $13 \%$ in germinated and fortified preparation and increase lysine to more than $50 \%$ when cowpea is added (12). It is advisable to add palm oil to the weaning gruel to improve the vitamin A content Anglani (14) did a good review in the use of sorghum for human foods. Fortification is done either to improve the taste and acceptability enjoyed by commercial (baby weaning) products like cerelac for nutritional purpose. Local fortification for taste include use of sugar, milk, chocolate, "kulikuli" (ground nut cake), fried beans (i.e. beans cake or 'Akara'), fruits and seed/berry often to dose the sour taste or enhance it. (11). Furthermore, ogi is an example of traditional fermented food, which has been upgraded to a semi-industrial scale (15). Traditional and industrial methods for manufacturing ogi have been reported (1). Microbiological and nutritional studies by Akinrele (7) showed that the lactic acid bacterium Lactobacillus plantarum the aerobic bacteria Corynebacterium and Aerobacter, the yeasts Candida mycoderma, Saccharomyces cerevisae and Rhodotorula and molds Cephalosporium, Fusarium, Aspergillus and Penicillium are the major organisms responsible for the fermentation and nutritional improvement of ogi. Odunfa (3) determined that L. planetarium was the predominantly organism in the fermentation, responsible for lactic acid production, Corynebacterium hydrolysed corn starch to organic acids while S. cerevisiae and Candida mycoderma contributed to flavor development. The millets happen to be the staple food in many parts of Africa, Asia, Central America and the Arab countries (16). The grain contains at least 9\% protein and a good balance of amino acids. It has more oil than maize and is high-energy cereal. Moreover, it has been proved scientifically that breast milk is the perfect food for infant during the first six months of life. It contains every nutrient and immunological factor an infant requires to maintain optimal health and growth. It also protects infants against the two leading causes of infant mortality, upper respiratory infections and diarrhea (17). However, at the age of six months and above when the child's birth weight is expected to have doubled, breast milk is no longer sufficient to meet the nutritional needs of the growing infant. Nutritious complementary foods are therefore introduced, also known as weaning foods which majorly covers the period from six to twenty-four months of age in most developing countries (18). Nowadays, due to the reduced consumption of breast milk, important nutrients such as proteins, zinc, iron and $\beta$ vitamins are likely to be deficient in the contemporary diet of the affected infants (19). If such a development is not well handled during this crucial growth period, it can lead to under-nutrition. For instance, poor feeding practices or short fall in food intake have been known as the most direct factor responsible for malnutrition and illness amongst children (20). The result of this quality assessment of ogi from fermented millet is a versatile tool in Nigeria and many other countries where the infants, children and adults have been found most to be consumers of this food. 
It would also help drastically to reduce the deficiencies emanated from poor diets especially in infants at their beginning of life.

\subsection{Collection of samples}

\section{Materials And Methods}

Millets were purchased from Atakumosa market, Ilesa in Osun State, Nigeria from different sellers of the grains. The grains were properly dried after being purchased and mixed together before ogi is prepared.

\subsection{Methods}

\subsubsection{Preparation of dry milled ogi from fermented millet (unmalted)}

The millet grains were washed, steeped for $72 \mathrm{~h}$ and the water is drained. The fermented grains were dried, milled, sieved and packaged (21).

\subsubsection{Preparation of dry milled ogi from malted millet}

Millet grain was malted according to the method described by Okoli and Adeyemi (22). The millet grains were screened from dirts and weighed. It was then steeped in water at $30^{\circ} \mathrm{C}$ for $18 \mathrm{~h}$. The steeped grains were washed for three times at $6 \mathrm{~h}$ intervals to dis-allow fermentation. The grains were kept on a jute bag and covered, wet with water and left in a dark cupboard to germinate at room temperature $\left(30^{\circ} \mathrm{C}\right)$ for $72 \mathrm{~h}$. The germinated grains were sun-dried, 5\% and $10 \%$ malted samples were prepared by mixing malted millet and unmalted samples in 1:19(w/w) and 1.9(w/w), respectively. Each of the samples was fermented for $72 \mathrm{~h}$. It was sun-dried, milled, sieved and packaged.

\subsubsection{Physico-chemical and Proximate analysis of ogi flour.}

The $\mathrm{pH}$, crude fibre, moisture content, protein and fat of the sample were determined using AOAC method (23). Also, the viscosity was determined by the method of Mosha and Swanberg (24). Carbohydrate was calculated by difference.

III. Results And Discussion

Table 1:Some physico-chemical and proximate composition of ogi samples (\%)

\begin{tabular}{|l|l|l|l|}
\hline \multicolumn{3}{|c|}{ SAMPLES } \\
\hline Parameters & 0\% Malted Ogi & 5\% Malted Ogi & $\mathbf{1 0 \%}$ Malted Ogi \\
\hline $\mathrm{pH}$ & 5.49 & 5.13 & 4.89 \\
\hline Ash (\%) & 1.18 & 1.38 & 2.00 \\
\hline Crude fibre (\%) & 2.78 & 3.38 & 3.98 \\
\hline Moisture content (\%) & 8.88 & 8.98 & 9.47 \\
\hline Protein (\%) & 13.21 & 14.33 & 15.39 \\
\hline Fat (\%) & 5.23 & 4.48 & 4.33 \\
\hline Viscosity (c $\left.{ }^{P}\right)$ & 10.35 & 6.148 & 5.058 \\
\hline Carbohydrate & 70.00 & 67.83 & 65.24 \\
\hline
\end{tabular}

\section{Quality Evaluation}

The ogi porridge consumers who were familiar with its quality were used as panels to evaluate the product. Selection was based on interest. The ogi porridge was prepared by mixing $40 \mathrm{~g}$ ogi flour in $20 \mathrm{ml}$ of water and $12 \mathrm{~g}$ sugar with boiling water to gelatinization. After its preparation, it was sieved at random to the assessors while hot in plates. The assessors were seated beside one another in a earmarked room. The colour/appearance, flavor and consistency were used for rating the quality of the ogi's. The overall acceptability of the samples was rated as well. Data for all parameters were reported based on ten assessors.

\section{Discussion}

From the analysis, it is found that the $\mathrm{pH}$ of the ogi flour decreased with increase in the level of malt (table 1). The decrease in $\mathrm{pH}$ of the ogi flour is due to organic acids (3). The lower $\mathrm{pH}$ shows that the ogi flour is not liable to spoilage. Also, the percentage moisture increased with the level of percentage of the malted ogi from $8.88-9.47$ respectively (Table1). The protein increases with the levels of percentage of the malted ogi (table 1), this increase level is similar with the ogi made from malted corn (22). The increase in the level of the protein may be due to dry matter loss during germination. Hence, this increase would improve the nutrition of infants and children, especially in Nigeria and some other countries of the world where the millet is consumed in a greater quantity. The ash content also increase in this study and it appears that there is no much loss in ash content rather, it increase, thus, there are mineral contents in ogi made from malted grains. Furthermore, the fat content was reduced in the malted ogi, which shows that the fat was broken down drastically (Table 1). The 
viscosity varies among the samples, level of percentage (Table 1) in which $10 \%$ malted ogi has the lowest. This is due to starch germination and enzyme hydrolysis (22). The breakdown in the fat contents may be due to the hours of exposure onto which the grains germinated. It also occurs after germination period (after 18h), thus, helps to improve the shelf-life of the ogi (25). The crude fibre of the malted flour also increase from 2.78 to 3.98 and the increase in the levels suggest the quality of the malted ogi because the increase also improve the shelflife of the product (25). Malting and fermentation reduces the carbohydrate content (table 1). Finally, all the samples (malted ogi) were rated acceptable unlike unmalted ogi samples through appearance, flavor and consistency. Hence, the malted ogi's were accepted by the assessors without any significant difference.

\section{Conclusion}

The malted ogi is therefore preferable to unmalted ogi based on the results of this study shown above. This could effectively improve the nutritional diets of infants, children and the adults at large. This would also serve as tool to reduce ailments threatening the infants and children especially.

\section{References}

[1] E.O.I. Banigo and H.C Muller, carboxylic acids pattern in ogi fermentation J.Sci.Food Agr., 23, (1972a), $101-111$.

[2] J.O. Akingbala, L.W. Rooney and J.A. Faubion, A laboratory procedure for the preparation of ogi: A Nigerian fermented food. J.Food Sci., 46, (1981), 1523-1526.

[3] S.A. Odunfa, African fermentation foods. In microbiology of fermentation foods vol. 2, (1985), Ed. BJB wood pp. 151-191. Elsevier Publishers, London.

[4] J.B. Fashakin, 1989. Nutritional evaluation of weaning foods. In. Fashakin, J.B, (Ed.), Proceedings of the workshop on present knowledge on weaning foods in Nigeria. Federal Institute or Industrial Research, Lagos Oshodi-Lagos, pp: 115-20.

[5] T.G. Sokari, Improving the nutritional quality of ogi and Gari. Applications of biotechnology to traditional fermented foods. National Academic Press, (1992), Pp. 93.

[6] S.O. Ighedioh, A.O. Ogbeni and C.M. Adole, Infans weaning practices of some Tiv women resident in Makurdi, Nigeria. Nut. Health, 11(1), (1996), 13-28.

[7] I.A. Akinrele, Fermentation studies on sorghum during the preparation of traditional African starch-cake food. J.Sci. Food Agr., 21, (1970), 619-625.

[8] V.B. Akanbi, I. Adeonowaye, A. Ojo and I.A Adeyemi, Effect of processing factors on rheological properties of ogi. Int.J.Food Prop; 6, (2003), 405-418.

[9] O. F. Osundahunsi, and O. C. Aworh, Nutritional evaluation, with emphasis on protein quality of maize-based complementary foods enriched with soya bean and cowpea tempe. Int. J. Food Sci. Technol., 38, (2003), 809-813.

[10] J.O. Akingbala, B.A. Akinwande and P.I. Uzo-Peters, Effects of color and flavor changes on acceptability of ogi supplemented with okro seed meals. Plant food. Hum. Nutr., (formerly Qualitas Plantarum), 58(3), (2005), 1-9.

[11] A.I. Sanni, M. Asiedu and G.S. Ayernor, Influence of processing conditions on the nutritive value of ogi-baba, a Nigerian fermented sorghum gruel. Plant food Hum. Nutr., 56(3), (2001), 217-223(7).

[12] M. Egounlety, O.C. Aworh, J.O. Akingbala, J.H. Houben and M.C. Nago, Nutritional and sensory evaluation of tempe-fortified maize-based weaning foods. Int.J.Food Sci. Nut., 53(1), (2002), 15-27.

[13] N. M. Nnam, Chemical evaluation of multi-mixes formulated from some local staples for use as complementary food in Nigeria. Plant Food. Hum. Nutri. (Formerly Qualitas plantarum), 55(3), (2000), 255-263.

[14] C. Anglani, Sorghum for human food- A review plant food. Hum. Nutr., (Formerly Qualitas Plantarum), 52(1), (1998), 85-95.

[15] O.K. Achi, The potential of upgrading traditional fermented foods through biotechnology. Afr.J.Biotechnol 4(5), (2005), 375-380.

[16] N.I Kent, Technology of cereals: An introduction for students of food science and agriculture. $3^{\text {rd }}$ Edition: Pergamon Press Ltd. (1983), Pp. 102.

[17] UNICEF. Breastfeeding: Foundation for a healthy future UNICEF, New York 1999

[18] FAO. Sorghum and Millets in Human nutrition. FAO food nutrition series 27,1995.

[19] N.H. Khan, R. Bressan, Preparation and nutritional quality of high protein food extracts from immature corn, whole soybean and dry whole milk. Plant food human nutrition 37, (1987), 141-9.

[20] I.A Adeyemi, O. Beckley, Effect of period of maize fermentation and souring on chemical properties and amylograph viscosity of ogi. J. cereal Sc. 4, (1986), 352-360

[21] I.A Adeyemi, Dry milling of sorghum for ogi manufacture, J.Cereal Sc. 1, (1983), 221-227.

[22] E.C. Okoli, I.A Adeyemi, Manufacturing of ogi from malted (germinated) corn (zea mays): evaluation of chemical, pasting and sensory properties. J.Food Sc.54, (1989), 971-973.

[23] AOAC, 1984. Official methods of Analysis. $13^{\text {th }}$ Edn., Association of Agricultural chemists Washington D.C. Academic and Professional Presses, 1995, pp:398-407.

[24] A.C Mosha, U. Swanberg, Preparation of weaning foods with high nutrient density using flour of germinated cereals. Food and nutrition Bulletin 5(2), (1983), 10-14.

[25] A.R. Opoku, A.U. Osagie, E.R. Ekerigin, Changes in the major constituents of millet during germination. J. Agric. Food Chem. 31, (1983), 507-509. 